\title{
PENGGUNAAN MEDIA EDUKASI GIZI APLIKASI ELECTRONIC DIARY FOOD (EDIFO) DAN METODE PENYULUHAN SERTA PENGARUHNYA TERHADAP PENGETAHUAN IBU HAMIL
}

\author{
${ }^{1}$ Dewi Mey LM, ${ }^{2}$ Rita Ridayani, ${ }^{3}$ Neny San AS. ${ }^{4}$ Jusuf Kristianto, ${ }^{5}$ Muslim. \\ 1,2,3 Jurusan Kebidanan, Politeknik Kesehatan Kemenkes Tanjungpinang, Indonesia \\ ${ }^{4}$ Politeknik Kesehatan Kemenkes Jakarta 1, Indonesia \\ ${ }^{5}$ Dinas Kesehatan Kabupaten Bintan, Indonesia
}

Info Artikel Abstrak

\section{Genesis Naskah:}

Submitted:25-2-2020.

Revised:13-5-2020, 18-5-

2020, 26-5-2020.

Accepted: 26-5-2020

Kata Kunci:

EDIFO, Pengetahuan Ibu

Hamil
Masalah kesehatan masyarakat yang utama di negara berkembang termasuk Indonesia ialah masalah gizi. Ibu hamil merupakan salah satu populasi yang sangat rentan terkena masalah gizi. Jarangnya ibu hamil melakukan konsultasi menu makanan kepada ahli gizi dapat berakibat pada bertambahnya angka kematian bayi di Indonesia. Penelitian ini bertujuan untuk mengetahui pengaruh penggunaan aplikasi electronic diary food (EDIFO) terhadap pengetahuan ibu hamil tentang gizi seimbang. Desain Penelitian ini merupakan penelitian kuantitatif dengan rancangan eksperimen semu (Quasi Eksperiment) dengan desain one group pre test and post test design dengan sampel ibu hamil di wilayah kerja Puskesmas Kota Tanjungpinang sebanyak 43 responden. Penelitian dilakukan pada bulan April sd Oktober 2019 dengan hasil didapatkan pengetahuan pre-test dalam metode penyuluhan dan android pada katagori cukup dengan nilai median 66,67 dan rentang 60-77, sedangkan pada post test penyuluhan masuk dalam katagori baik dengan nilai median 81,67 dan rentang 80-90. dan Metode android masuk dalam katagori baik dengan nilai median 100 dan rentang 83-100. Pengetahuan dalam metode penyuluhan persentase peningkatan sebesar 0,09\% dan untuk android sebesar 0,33\%. Hasil uji paired T-Test terdapat pengaruh pemberian penyuluhan dan aplikasi EDIFO dapat meningkatkan pengetahuan secara bermakna $(\mathrm{P}=0,000)$ tentang gizi seimbang secara bermakna $(\mathrm{P}=0,002)$. Untuk pengetahuan dalam metode penyuluhan persentase peningkatan sebesar $0,09 \%$ dan untuk android sebesar 0,33\%. Terdapat pengaruh penggunaan aplikasi Electronic Diary Food (EDIFO) terhadap pengetahuan ibu hamil tentang gizi seimbang. Diharapkan ibu lebih memperhatikan asupan makanan yang diberikan dengan menu yang bervariasi.

\section{USE OF ELECTRONIC DIARY FOOD (EDIFO) APPLICATIONS AND ITS EFFECT ON PREGNANT MOTHER KNOWLEDGE}

Keywords:

EDIFO, Knowledge of

Pregnant Women

\begin{abstract}
The main public health problem in developing countries including Indonesia is nutrition. Pregnant women are one of the populations that are very susceptible to nutrition problems. Rarely do pregnant women consult a dietary dietitian to have an effect on increasing infant mortality in Indonesia. This study aims to determine the effect of the use of electronic diary food (EDIFO) applications on pregnant women's knowledge of balanced nutrition. Design This study is a quantitative study with quasi-experimental design (Quasi Experiment) with one group pretest and post-test design design with samples of pregnant women in the working area of Tanjungpinang Health Center as many as 43 respondents. The study was conducted in April to October 2019 with the results obtained pre-test knowledge in counseling methods and android on
\end{abstract}

(C) Poltekkes Kemenkes Jakarta I

J1. Wijaya Kusuma No. 47-48 Cilandak Jakarta Selatan, Indonesia email: jurnalquality@poltekkesjakarta1.ac.id
ISSN 2655-2434

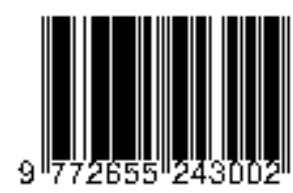


the category enough with a median value of 66.67 and a range of 60-77, while the post-test counseling included in the category both with a median value of 81.67 and the range 80-90. and Android method is included in both categories with a median value of 100 and a range of 83-100. Knowledge in the extension method percentage increased by $0.09 \%$ and for android amounted to $0.33 \%$. Paired T-Test results show that the effect of counseling and EDIFO application can significantly increase knowledge $(P=0,000)$ about balanced nutrition significantly $(P=0.002)$. For knowledge in counseling methods the percentage increase was $0.09 \%$ and for android it was $0.33 \%$. There is an influence of the use of the Electronic Diary Food (EDIFO) application on the knowledge of pregnant women about balanced nutrition. It is expected that mothers pay more attention to the intake of food provided with a varied menu.

\author{
Korespondensi Penulis: \\ Dewi Mey Lestanti Mukodri \\ Jurusan Kebidanan Poltekkes Kemenkes Tanjungpinang \\ Email: mysyahla@gmail.com
}




\section{Pendahuluan}

Masalah kesehatan masyarakat yang utama di Negara berkembang termasuk di Indonesia yaitu masalah gizi. Masalah gizi merupakan penyebab kematian ibu dan anak secara tidak langsung yang sebenarnya masih dapat dicegah. Pada masa kehamilan zat gizi diperlukan untuk pertumbuhan organ reproduksi ibu. (Mariana et al., 2018; Puli et al., 2014)

Ibu hamil merupakan golongan yang termasuk rawan terhadap masalah gizi. Terdapat beberapa faktor yang memengaruhi status gizi ibu hamil salah satunya ialah pengetahuan zat gizi dalam makanan. Kebutuhan gizi seorang wanita selama kehamilan mengalami peningkatan untuk beberapa zat gizi tertentu. Zat gizi pada seorang wanita dapat terpenuhi apabila hati hati dalam memilih makanan. (Handayani, 2014)

Hasanah et al., 2013 menyatakan bahwa pemenuhan zat gizi selama kehamilan tersebut dikatakan cukup apabila memiliki kebiasaan makan yang baik. Kebiasaan makan merupakan suatu istilah untuk menggambarkan kebiasaan dan perilaku yang berhubungan dengan makanan antara lain seperti pola makanan yang dimakan, frekuensi dan porsi makanan, kepercayaan dan penerimaan terhadap makanan (misalnya pantangan dan rasa suka atau tidak suka terhadap makanan), dan cara pemilihan bahan makanan yang hendak dimakan.

Hasil penelitian Narasiang et al., 2016 tentang gambaran pola konsumsi makanan pada ibu hamil di kota Manado dapat disimpulkan bahwa mengacu pada Permenkes nomor 75 tahun 2013 tentang Angka Kecukupan Gizi di Indonesia, ibu hamil di Kota Manado memiliki pola makan yang rendah karbohidrat $(159,97 \mathrm{gr} / \mathrm{hari})$, cukup protein $(79,15 \mathrm{gr} / \mathrm{hari})$ dan tinggi lemak $(124,74 \mathrm{gr} /$ hari). Beras merupakan bahan makanan sumber karbohidrat yang paling banyak dikonsumsi ibu hamil di Kota Manado yaitu sebanyak 303,67gr/hari, ikan air laut merupakan bahan makanan sumber protein yang paling banyak dikonsumsi ibu hamil di Kota Manado yaitu sebanyak 102,55 gr/hari, dan minyak kelapa merupakan bahan makanan sumber lemak yang paling banyak dikonsumsi ibu hamil di Kota Manado yaitu sebanyak 118,63 gr/hari.

Menurut Peraturan Menteri Kesehatan (PMK) masalah gizi dapat dicegah dengan melakukan kegiatan sosialisasi Pedoman Gizi Seimbang yang bisa dijadikan sebagai panduan makan terutama pada ibu hamil. Upaya pengoptimalan penyampaian pesan gizi seimbang pada ibu hamil diperlukan informasi, komunikasi, dan edukasi yang tepat. Sistem informasi terkait kebutuhan gizi bisa didapatkan melalui alat komunikasi untuk dapat membantu ibu hamil dalam menjaga kesehatan kehamilannya dan mengontrol asupan makanan serta mengetahui berbagai jenis makanan tambahan berbasis pangan lokal (Kementrian Kesehatan RI, 2014; Rahim et al., 2018)

Ibu hamil saat ini hanya memeriksakan keadaan kandungan nya ke tenaga kesehatan. Kesehatan kandungan sesungguhnya bergantung pada jenis - jenis makanan yang dimakan oleh ibu, sebab dari makanan itulah zat - zat gizi yang dibutuhkan oleh janin untuk tumbah dan bekembang didapatkan. Saat ini ibu hamil dapat mengetahui konsumsi makanan yang harus dipenuhi melalui ahli gizi, akan tetapi ibu hamil jarang sekali berkonsultasi kepada ahli gizi mengenai pola makan dan jenis menu makanan yang harus dikonsumsi. Jarangnya ibu hamil melakukan konsultasi menu makanan kepada ahli gizi dapat berakibat pada bertambahnya angka kematian bayi di Indonesia.

Untuk membantu ibu hamil dalam mengontrol kebutuhan gizinya dan menyelesaikan permasalahan diatas maka akan dibuat sebuah aplikasi Electronic Diary Food (EDIFO) sebagai sistem informasi asupan gizi seimbang pada ibu hamil. Seorang ibu hamil dapat mengakses aplikasi sistem informasi asupan gizi seimbang dimanapun dan kapanpun.

Berdasarkan data Dinas Kesehatan Kota Tanjungpinang tahun 2018 terdapat jumlah ibu hamil sebanyak 4.451 orang yang tersebar di 7 puskesmas kota tanjungpinang, Puskesmas kota Tanjungpinang merupakan salah satu puskesmas yang memiliki sasaran ibu hamil paling banyak dengan jumlah ibu hamil sebanyak 1.032 orang, dari jumlah tersebut masih terdapat ibu hamil dengan Kekurangan Energi Kronik (KEK) dan Anemia. Status gizi ibu hamil dapat kita ketahui dari kegiatan pemantauan pertambahan berat badan selama hamil, mengukur Lingkar Lengan Atas (LILA) dan mengukur kadar $\mathrm{Hb}$. Hal tersebut diduga akibat dari kurangnya pengetahuan ibu hamil mengenai gizi seimbang yang dapat diperoleh ibu hamil dalam kebiasaan makan sehari-hari.

Melihat data dan laporan tersebut penulis ingin melakukan penelitian penggunaan aplikasi berbasis android Electronic Diary Food (EDIFO) serta pengaruhnya terhadap pengetahuan tentang gizi seimbang pada ibu hamil di wilayah kerja Puskesmas Tanjungpinang Tahun 2019 dengan menggunakan smartphone yang merupakan salah satu kemajuan teknologi dewasa ini serta mayoritas masyarakat sudah menggunakan kemajuan teknologi tersebut. 


\section{Metode}

Penelitian ini merupakan penelitian kuantitatif dengan rancangan eksperimen semu (Quasi Eksperiment) dengan desain one group pre test and post test design. Rancangan penelitian ini menggunakan pretest terlebih dahulu sebelum diberi perlakuan, dengan demikian hasilnya akan lebih akurat karena dapat membandingkan keadaan sebelum dan sudah diberi perlakuan, yaitu untuk menilai penggunaan aplikasi EDIFO serta pengaruhnya terhadap pengetahuan tentang gizi seimbang pada ibu hamil.

Variabel dalam penelitian ini terdiri dari Variabel bebas (independent variable) yaitu aplikasi Electronic Diary Food (EDIFO), variabel terikat (dependence variable) yaitu pengetahuan dan sikap ibu hamil tentang gizi seimbang dan variabel perancu (confounding variabel) yaitu usia, pendidikan, pekerjaan, dan pendapatan keluarga.

Populasi target dalam penelitian ini adalah semua ibu hamil yang ada di wilayah kerja Puskesmas Kota Tanjungpinang berdasarkan data bulan Januari - Maret 2019 yaitu sebanyak 75 orang. (Puskesmas Kota Tanjungpinang). Populasi terjangkau dalam penelitian ini adalah ibu hamil yang ada di lingkup wilayah Kerja Puskesmas Kota Tanjungpinang yang memenuhi kriteria inklusi dan eksklusi dengan data dari bulan Januari - Maret 2019.

Pengambilan sampel dalam penelitian ini menggunakan teknik sampling probability sampling dimana merupakan teknik pengambilan sampel yang memberikan peluang yang sama kepada setiap anggota populasi untuk menjadi sampel dengan menggunakan simple random sampling. Sampel diambil secara acak, tanpa memerhatikan tingkatan yang ada dalam populasi, tiap elemen populasi memiliki peluang yang sama dan diketahui untuk terpilih sebagai objek. Sampel pada penelitian ini adalah ibu hamil di wilayah kerja Puskesmas Kota Tanjungpinang pada periode penelitian yang memenuhi kriteria inklusi dan tidak termasuk kriteria eksklusi serta bersedia mengikuti penelitian dengan menandatangani lembar persetujuan responden.
Jumlah sampel ditentukan menggunakan rumus slovin yang dapat merepresentasi populasi yang ada dan dapat mengurangi bias dalam pengambilan sampel dengan tingkat kesalahan $10 \%$ yang sangat cocok dengan teknik pengambilan data menggunakan simple random sampling.

Kriteria inklusi pada penelitian ini yaitu sehat secara jasmani dan rohani, Memiliki smartphone dan mampu mengoprasikannya, Ibu hamil mau mengikuti kegiatan sosialisasi Aplikasi Electronic Diary Food (EDIFO), kemudian Kriteria eksklusi yaitu Ibu hamil yang tidak mau mengikuti sosialisasi EDIFO dengan utuh, sedangkan Kriteria Drop Out yaitu Ibu yang sudah melahirkan saat dilakukan penelitian, Ibu hamil yang mengundurkan diri sebagai responden saat penelitian berlangsung dan Ibu yang handphonenya rusak saat penelitian.

Instrumen pengumpulan data yaitu : Alat yang digunakan dalam penelitian ini adalah Formulir persetujuan kesediaan menjadi responden (informed consent), Lembar kuesioner pengetahuan tentang gizi seimbang. Teknik pengumpulan data diambil dengan menggunakan Angket atau kuesioner. Angket atau kuesioner merupakan teknik pengumpulan data yang dilakukan dengan memberikan sejumlah pertanyaan atau pernyataan tertulis kepada responden untuk dijawabnya. Data variabel pengetahuan, diambil menggunakan penyebaran angket/kuesioner.

Pengolahan data Kuantitatif dilakukan dengan langkah Edit data, pemberian kode, entry data, dan pembersihan data. Kemudian data dianalisis secara univariate dan bivariate. Analisis univariat dilakukan untuk data karakteristik ibu hamil yaitu usia, pendidikan, pekerjaan, dan pendapatan. Kemudian untuk mengetahui perbedaan rerata 2 variabel dengan skala numerik dan kategorik. Uji statistic digunakan karena data tidak terdistribusi normal maka uji $\mathrm{T}$ Independen tidak dapat digunakan, maka digunakan Uji Nonparametrik yaitu Mann Whitney Test. Dan perbedaan tersebut dianggap bermakna apabila hasil uji $p$ value < 0,005 . 
Hasil

Tabel 1. Distribusi Frekuensi Karakteristik Responden Penelitian $(n=43)$

\begin{tabular}{lcc}
\hline \multicolumn{1}{c}{ Karakteristik Responden } & $\mathbf{n}$ & $\mathbf{\%}$ \\
\hline Usia & 1 & 2,3 \\
$\quad<20$ tahun & 37 & 86,1 \\
20-35 tahun & 5 & 11,6 \\
$\quad>35$ tahun & 5 & 11,6 \\
Pendidikan & 22 & 51,2 \\
$\quad$ SD/SMP & 16 & 37,2 \\
$\quad$ SMA/Sederajat & & \\
$\quad$ Perguruan Tinggi & 27 & 62,8 \\
\hline Pekerjaan & 16 & 37,2 \\
$\quad$ Tidak Bekerja & & \\
$\quad$ Bekerja & 14 & 32,6 \\
\hline Pendapatan & 29 & 67,4 \\
$\quad$ Rendah $(<R p 2.500 .000)$ & \\
$\quad$ Tinggi $(\geq \operatorname{Rp} 2.500 .000)$ &
\end{tabular}

Berdasarkan tabel 1 dapat diketahui bahwa distribusi frekuensi karakteristik responden penelitian dari 43 ibu hamil di wilayah kerja Puskesmas Tanjungpinang pada karakteristik responden berdasarkan usia yang ikut serta dalam penelitian ini paling banyak berusia 20-35 tahun sebesar 86,1 \% responden, sisanya berusia $>35$ tahun sebesar 11,6\% responden dan berusia $<20$ tahun sebesar 2,3 \% responden. Karakteristik responden berdasarkan pendidikan yang paling banyak sebesar 51,2 \% reponden berpendidikan SMA, sementara sisanya sebesar $11,6 \%$ responden berpendidikan SD/SMP dan sebesar 37,2 \% responden berpendidikan perguruan tinggi. Karakteristik responden berdasarkan pekerjaan yang terlibat paling banyak dalam penelitian ini sebesar $62,8 \%$ responden tidak bekerja, sementara sisanya sebesar 37,2 \% responden bekerja. Selanjutnya karakteristik responden berdasarkan pendapatan keluarga paling banyak sebesar $67,4 \%$ responden berpenghasilan $\geq U M R$, sementara sisanya sebesar $32,6 \%$ responden berpenghasilan. $<\mathrm{UMR}$.

\section{Pengaruh Pengetahuan Ibu Sebelum dan Sesudah Diberikan Intervensi}

Tabel 2. Pengetahuan Ibu Sebelum dan Sesudah Diberikan Intervensi

\begin{tabular}{|c|c|c|c|c|c|c|}
\hline \multirow{2}{*}{$\begin{array}{l}\text { Penge } \\
\text { tahuan }\end{array}$} & \multicolumn{3}{|c|}{ Penyuluhan } & \multicolumn{3}{|c|}{ Android } \\
\hline & $\begin{array}{l}\text { Me } \\
\text { dian }\end{array}$ & $\begin{array}{l}\text { Ren } \\
\text { tang }\end{array}$ & $\begin{array}{c}\text { Nilai } \\
\mathrm{p}\end{array}$ & $\begin{array}{l}\text { Me } \\
\text { dian }\end{array}$ & $\begin{array}{l}\text { Ren } \\
\text { tang }\end{array}$ & $\begin{array}{c}\text { Nilai } \\
\mathrm{p}\end{array}$ \\
\hline Pre-test & & & & & & \\
\hline $\begin{array}{l}\text { Baik } \\
(\geq 80 \%)\end{array}$ & 0 & 0 & & 0 & 0 & \\
\hline $\begin{array}{l}\text { Cukup } \\
(60-79 \%)\end{array}$ & 66,67 & $60-77$ & & 66,67 & $60-77$ & \\
\hline $\begin{array}{l}\text { Kurang } \\
(\leq 59 \%)\end{array}$ & 51,67 & $43-57$ & & 51,67 & $43-57$ & \\
\hline Post-test & & & $0,000^{\mathrm{a}}$ & & & $0,000^{\mathrm{b}}$ \\
\hline $\begin{array}{l}\text { Baik } \\
(\geq 80 \%)\end{array}$ & 81,67 & $80-90$ & & 100 & $83-100$ & \\
\hline $\begin{array}{l}\text { Cukup } \\
(60-79 \%)\end{array}$ & 68,33 & $63-77$ & & 0 & 0 & \\
\hline $\begin{array}{l}\text { Kurang } \\
(\leq 59 \%)\end{array}$ & 53,33 & $47-57$ & & 0 & 0 & \\
\hline
\end{tabular}

Ket: ${ }^{\text {a }}$ : hasil uji menggunakan Paired T-Test

${ }^{\mathrm{B}}$ : hasil uji menggunakan Wilcoxon

Berdasarkan tabel 2 data diperoleh pengetahuan ibu sebelum dan sesudah diberikan intervensi yaitu pengaruh pemberian penyuluhan dan aplikasi EDIFO dapat meningkatkan pengetahuan secara bermakna $(\mathrm{P}=0,000)$. Untuk pengetahuan pre-test dalam metode penyuluhan dan android pada katagori cukup dengan nilai median 66,67 dan rentang 60-77, sedangkan pada post test penyuluhan masuk dalam katagori baik dengan nilai median 81,67 dan rentang 80-90, kemudian Metode android masuk dalam katagori baik dengan nilai median 100 dan rentang 83-100.

Perbedaan Skor Pengetahuan Ibu hamil pada Kelompok Pre Test dan Post Test Sebelum dan Setelah diberikan Penyuluhan dan Aplikasi EDIFO

Analisis perbedaan skor awal (pre test) dan skor akhir (post test) pengetahuan ibu hamil tentang gizi seimbang, terlihat pada tabel di bawah ini : 
Tabel 3. Perbedaan Skor Pengetahuan Ibu Sebelum dan Sesudah Diberikan Intervensi

\begin{tabular}{|c|c|c|c|c|c|}
\hline \multirow{2}{*}{$\begin{array}{c}\text { Penge } \\
\text { tahuan }\end{array}$} & \multicolumn{2}{|c|}{ Penyuluhan } & \multicolumn{2}{|c|}{ Android } & \multirow[b]{2}{*}{$\begin{array}{c}\text { Nilai } \\
\mathrm{p}\end{array}$} \\
\hline & Pre-test & Post-test & Pre-test & $\begin{array}{c}\text { Post- } \\
\text { test }\end{array}$ & \\
\hline \multicolumn{6}{|l|}{ Pengetahuan } \\
\hline $\begin{array}{l}\text { Rata-rata } \\
\text { (SD) }\end{array}$ & $\begin{array}{c}62,64 \\
(9,130) \\
63,33\end{array}$ & $\begin{array}{c}71,86 \\
(10,346) \\
73,33\end{array}$ & $\begin{array}{c}62,64 \\
(9,130) \\
63,33\end{array}$ & $\begin{array}{c}97,6 \\
(3,513) \\
100\end{array}$ & 0,000 \\
\hline $\begin{array}{l}\text { Median } \\
\text { Rentang }\end{array}$ & $43-77$ & $47-90$ & $43-77$ & $83-100$ & \\
\hline $\begin{array}{l}\text { \%skor } \\
\text { pengetahuan }\end{array}$ & \multicolumn{2}{|c|}{$0,09 \%$} & \multicolumn{2}{|c|}{$0,33 \%$} & \\
\hline
\end{tabular}

Berdasarkan tabel 3 tampak perbedaan skor pengetahuan ibu sebelum dan sesudah diberikan intervensi, dimana pengaruh pemberian penyuluhan dan aplikasi EDIFO dapat meningkatkan pengetahuan secara bermakna $(\mathrm{P}=0,000)$ ibu hamil tentang gizi seimbang secara bermakna $(\mathrm{P}=0,002)$. Untuk pengetahuan dalam metode penyuluhan persentase peningkatan sebesar 0,09\% dan untuk android sebesar $0,33 \%$.

\section{Perbedaan peningkatan Pengetahuan Berdasarkan Karakteristik Responden}

Pengujian perbedaan peningkatan pengetahuan berdasarkan karakteristik responden dilakukan menggunakan uji Anova, Kruskal Wallis, dan Mann Whitney dimana kriteria pengujian disebutkan apabila $\mathrm{p}<0,05$ maka dapat dinyatakan bahwa ada perbedaan signifikan antara peningkatan pengetahuan sesudah pemberian penyuluhan dan aplikasi EDIFO berdasarkan usia, pendidikan, pekerjaan dan pendapatan keluarga dapat diketahui melalui tabel dibawah ini :

\section{Tabel 4. Perbedaan Peningkatan Pengetahuan Berdasarkan Karakteristik Responden}

\begin{tabular}{lccc}
\hline \multirow{2}{*}{ Karakteristik } & \multicolumn{3}{c}{ Pengetahuan } \\
\cline { 2 - 4 } & Median & Rentang & Nilai $\boldsymbol{p}$ \\
\hline Umur & & & \\
$\quad<20$ tahun & 56,67 & $50-97$ & $0,006^{\text {a }}$ \\
20-35 tahun & 73,33 & $43-100$ & \\
$\quad>35$ tahun & 80,00 & $57-100$ & \\
\hline Pendidikan & & & $<0,001^{\mathrm{b}}$ \\
\hline
\end{tabular}

(C) Poltekkes Kemenkes Jakarta I

Jl. Wijaya Kusuma No. 47-48 Cilandak Jakarta Selatan, Indonesia email: jurnalquality@poltekkesjakarta1.ac.id

\begin{tabular}{lccc}
\hline SD/SMP & 66,67 & $10-100$ & \\
SMA/Sederajat & 76,67 & $9,1-85,7$ & \\
Perguruan Tinggi & 73,33 & $7,1-50$ & \\
\hline Pekerjaan & & & \\
Tidak Bekerja & 72,67 & $7,1-85,7$ & $0.004^{\mathrm{c}}$ \\
Bekerja & 60,33 & $8,3-92$ & \\
\hline Pendapatan & & & \\
$\quad$ Rendah & & & \\
(<Rp2.500.000) & 65,33 & $9,1-100$ & $0,622^{\mathrm{c}}$ \\
Tinggi & 68,67 & $7,1-100$ & \\
$(\geq$ Rp2.500.000) & & & \\
\hline
\end{tabular}

Ket: ${ }^{\mathrm{a}}$ : hasil uji menggunakan Anova

b : hasil uji menggunakan Kruskal Wallis

${ }^{c}$ : hasil uji menggunakan Mann Whitney

Berdasarkan tabel 4 dapat diketahui pebedaan peningkatan pengetahuan berdasarkan karakteristik responden bahwa karakter responden yang meliputi usia, pendidikan, pekerjaan memiliki nilai $\mathrm{p}<0,05$ sedangkan pendapatan keluarga $\mathrm{p}>0,05$ maka usia, pendidikan, dan pekerjaan merupakan faktor perancu yang memiliki pengaruh terhadap peningkatan pengetahuan ibu.

\section{Pembahasan}

\section{Karakteristik Subjek}

Karakteristik responden pada penelitian ini terdiri dari usia ibu, pendidikan, pekerjaan dan pendapatan keluarga. Karakteristik tersebut perlu diamati karena merupakan variabel perancu yang dapat memengaruhi penelitian. Berdasarkan hasil pengujian yang tertera pada tabel 1 dapat dilihat karakteristik responden dalam penelitian ini berjumlah 43 ibu hamil yang meliputi usia, pendidikan, pekerjaan dan pendapatan keluarga.

Berdasarkan usia yang ikut serta dalam penelitian ini paling banyak berusia 20-35 tahun sebesar 86,1 \% responden, sisanya berusia $>35$ tahun sebesar 11,6\% responden dan berusia <20 tahun sebesar 2,3\% responden. Dari pengujian pada tabel 11 tentang perbedaan peningkatan pengetahuan berdasarkan usia didapatkan hasil terdapat perbedaan yang signifikan dengan nilai $\mathrm{p}<0,05$, peningkatan pengetahuan yang paling tinggi yaitu pada usia $<20$ tahun.

Usia dapat memengaruhi daya tangkap dan pola pikir seseorang sehingga pengetahuan yang diperoleh semakin baik. Pengetahuan seseorang

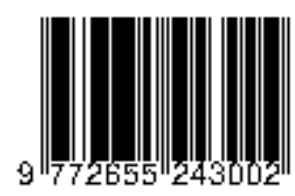


berkaitan dengan paparan media masa seperti media cetak dan elektronik. Seseorang yang sering terpapar dengan media elektronik maupun media masa seperti televisi (TV), radio, koran, majalah, handphone dan lain-lain memperoleh informasi yang lebih banyak dibandingkan dengan tidak terpapar. Sehingga usia yang lebih tua tidak menjamin pengetahuan seseorang lebih baik daripada usia yang lebih muda. (Wawan \& Dewi, 2011)

Berdasarkan pendidikan yang paling banyak sebesar 51,2 \% reponden berpendidikan SMA, sementara sisanya sebesar $11,6 \%$ responden berpendidikan SD/SMP dan sebesar 37,2 \% responden berpendidikan perguruan tinggi. Dari pengujian berdasarkan pendidikan didapatkan hasil terdapat perbedaan yang signifikan dengan $p<0,05$.

Pendidikan merupakan proses pemberdayaan peserta didik sebagai subjek dan objek dalam membangun kehidupan yang lebih baik. pendidikan juga merupakan proses sadar dan sistematis disekolah, keluarga, dan masyarakat untuk menyampaikan suatu maksud dari konsep yang sudah ditetapkan.

Menurut Afrilia, 2017 menyatakan bahwa kejadian gizi buruk yang terjadi pada ibu hamil rerata dengan tingkat pendidikan rendah (44\%). hubungan antara pendidikan ibu dengan pengetahuan tentang gizi seimbang. Hasil penelitian ini sesuai dengan penelitian Retnaningsih, 2010 yang mengatakan bahwa tingkat pendidikan memengaruhi tingkat pengetahuan ibu. Pendidikan berkaitan erat terhadap cara pandang atau pengetahuan seseorang dalam mempersepsikan sesuatu hingga membuat keputusan tertentu untuk masalah kesehatan mereka sendiri. Semakin tinggi pendidikan seseorang, maka semakin luas pengetahuannya. Namun, bukan berarti pendidikan rendah akan memiliki pengetahuan yang rendah pula. Hal ini dikarenakan peningkatan pengetahuan seseorang tidak hanya diperoleh dari pendidikan formal saja akan tetapi dapat pula diperoleh dari pendidikan non formal. Semakin tinggi tingkat pendidikan, semakin baik tingkat pengetahuan ibu tentang asupan gizi yang baik untuk ibu selama kehamilan.
Karakteristik responden berdasarkan pekerjaan yang terlibat paling banyak dalam penelitian ini sebesar $62,8 \%$ responden tidak bekerja, sementara sisanya sebesar $37,2 \%$. Hasil pengujian yang dilakukan tentang perbedaan peningkatan pengetahuan sesudah pemberian penyuluhan dan aplikasi EDIFO berdasarkan pekerjaan didapatkan hasil terdapat perbedaan yang signifikan dengan $\mathrm{p}<0,05$.

Hasil penelitian ini sesuai dengan penelitian Mamuroh et al., 2019 yang menunjukkan bahwa ibu yang tidak bekerja mempunyai pengetahuan yang lebih baik. Hal ini dikarenakan ibu yang tidak bekerja mempunyai waktu luang yang lebih banyak dalam mencari informasi tentang gizi bagi ibu hamil. Hal ini tidak sesuai dengan teori Notoatmodjo, 2012 yang menyatakan bahwa pekerjaan adalah pencaharian yang dijadikan pokok penghidupan atau sesuatu yang dilakukan untuk mendapatkan nafkah. Pekerjaan berhubungan erat dengan interaksi dengan orang lain. Jenis pekerjaan yang menuntut seseorang berinteraksi secara intens dengan orang yang mempunyai kemungkinan adanya transfers on knowledge.

Pendapat lain mengatakan bahwa pekerjaan suami atau istri turut menentukan kecukupan gizi ibu hamil dalam sebuah keluarga. Pekerjaan berhubungan dengan jumlah gaji yang diterima. Semakin tinggi kedudukan secara otomatis akan semakin tinggi penghasilan yang diterima, dan semakin besar pula jumlah uang yang di belanjakan untuk memenuhi kecukupan gizi ibu hamil dalam keluarga. Pekerjaan yang berhubungan dengan pendapatan merupakan faktor yang paling menentukan tentang kuantitas dan kualitas makanan. Hubungan yang erat antara pendapatan yang meningkat dan gizi yang didorong oleh pengaruh menguntungkan dari pendapatan yang meningkat bagi perbaikan kesehatan dan masalah keluarga lainnya yang berkaitan dengan keadaan gizi. Rendahnya pendapatan akan memengaruhi daya beli memungkinkan untuk mengatasi kebiasaan makan dengan cara-cara tertentu yang menghalangi perbaikan gizi yang efektif, terutama untuk anak-anak mereka. (Almatsier, 2011) 
Selanjutnya karakteristik responden berdasarkan pendapatan keluarga paling banyak sebesar $67,4 \%$ responden berpenghasilan $\geq \mathrm{UMR}$, sementara sisanya sebesar $32,6 \%$ responden berpenghasilan.<UMR. Pengujian yang dilakukan tentang perbedaan peningkatan pengetahuan sesudah pemberian penyuluhan dan aplikasi EDIFO berdasarkan pendapatan keluarga didapatkan hasil terdapat perbedaan yang signifikan dengan $p<0,05$.

Menurut Retnaningsih, 2010 bahwa semakin tinggi pendapatan akan semakin besar nilai nominal yang dibelanjakan untuk pangan tetapi persentasenya menurun. Salah satu faktor yang sangat menentukan kecukupan gizi adalah pendapatan. Pendapatan menunjukkan kemampuan keluarga untuk membeli pangan yang rendah tidak cukup untuk membeli makanan yang dibutuhkan. Walaupun pengeluaran untuk pangan lebih dari setengah pendapatan keluarga tetapi karena pendapatan keluarga rendah maka jumlah yang dibelanjakan untuk pangan juga rendah. Daya beli yang rendah menyebabkan ketersediaan makanan di tingkat keluarga juga kurang yang pada akhirnya berakibat tingkat konsumsi keluarga lebih rendah dari kecukupannya.

\section{Pengaruh Penerapan Penyuluhan dan Aplikasi Electronic Diary Food (EDIFO) Terhadap Peningkatan Pengetahuan Ibu Hamil tentang Gizi Seimbang}

Pengetahuan yang diperoleh dapat berasal dari pengalaman sendiri ataupun pengalaman orang lain. Berdasarkan hasil pengukuran yang tertera pada tabel 10 dapat dilihat terdapat peningkatan pengetahuan setelah diberikan perlakuan berupa penyuluhan dan aplikasi EDIFO dengan nilai $\mathrm{p}=0,000$. Hal ini berarti nilai $\mathrm{p}<0,05$, dengan demikian dapat dinyatakan bahwa terdapat perbedaan yang signifikan pengetahuan sebelum dan sesudah pemberian penyuluhan dan aplikasi EDIFO. Ditinjau dari nilai rata-rata, pengetahuan sesudah pemberian aplikasi EDIFO bernilai lebih tinggi dari pengetahuan sesudah pemberian penyuluhan dengan presentase peningkatan pengetahuan sebesar $0,33 \%$.
Hasil penelitian ini sejalan dengan penelitian Sudirman, 2016 yang menyebutkan bahwa pengetahuan orang tua tentang gizi berhubungan dengan diimplementasikan ke target pengguna yaitu ibu hamil yang menggunakan smartphone berbasis Android. Hasil pengujian white box testing menunjukkan aplikasi telah benar dan tidak memiliki kesalahan baik dari segi logika maupun fungsi dan layak untuk diimplementasikan. Hasil pengujian black box testing aplikasi telah benar dan tidak memiliki kesalahan fungsi pada semua bahan uji dan layak untuk diimplementasikan. Sedangkan berdasarkan hasil kuesioner ditarik kesimpulan bahwa dari segi kemudahan dalam penggunaan aplikasi, $12 \%$ responden menyatakan sangat mudah, $52 \%$ menyatakan mudah, $24 \%$ menjawab cukup mudah, $12 \%$ menjawab kurang mudah. Dari segi ketertarikan terhadap aplikasi, 36\% responden menyatakan sangat tertarik, 56\% menyatakan tertarik, $8 \%$ menjawab cukup tertarik. Pada indikator ketiga yaitu dari segi fungsionalitas, sebanyak $92 \%$ responden menyatakan aplikasi ini berfungsi dengan baik, $8 \%$ menjawab baik. Kemudian Tingkat pengetahuan seseorang erat kaitannya dengan tingkat Pendidikan formal, semakin tinggi pendidikan formal seseorang maka semakin mudah orang tersebut mengerti tentang hal-hal yang berhubungan dengan gizi seimbang. Sebagian besar tingkat pendidikan responden yaitu SMA sehingga pengetahuan mereka tentang gizi seimbang pada ibu hamil dalam kategori cukup.

Hasil penelitian ini terbukti bahwa dengan metode android dapat membantu ibu hamil secara mudah, aplikatif, dan efisien dalam meningkatkan pengetahuan gizi seimbang pada ibu hamil di sekitar wilayah Puskesmas Tanjungpinang, hal ini sesuai dengan teori yang menyebutkan bahwa peningkatan pengetahuan dipengaruhi oleh beberapa faktor, salah satunya adalah media massa dan media elektronik. Penggunaan media dalam pendidikan kesehatan bertujuan untuk menimbulkan perhatian terhadap suatu masalah dan mengingatkan informasi yang disampaikan supaya menimbulkan perubahan pengetahuan. Walaupun ada metode lainnya yaitu 
penyuluhan yang merupakan suatu program pemerintah yang dilakukan oleh petugas kesehatan di wilayah kerja, namun hasil perolehan yang didapatkan tidaklah cukup baik untuk meningkatkan segi pengetahuan ibu tentang gizi seimbang. Metode penyuluhan ini ada beberapa tahap metode pendidikan individual (konseling dan wawancara), metode pendidikan kelompok (ceramah, seminar, diskusi kelompok, memainkan peran, simulasi, bola salju dan curah pendapat) dan metode pendidikan massa (ceramah umum dan pidato melalui media massa). Metode diskusi kelompok mempunyai kelebihan yaitu masalah dapat dibahas dan dipecahkan bersama sehingga terjadi interaksi langsung antara peserta diskusi yang terlibat, peserta diskusi dapat bertukar pengalaman tentang permasalahan, informasi dan peserta diskusi dapat memecahkan masalah secara bersama-sama. (Deviyanty et al., 2017)

Hal ini sejalan dengan penelitian yang telah dilakukan oleh Perdana et al., 2017 terkait pengembangan media edukasi gizi berbasis android dan website serta pengaruhnya terhadap perilaku tentang gizi seimbang siswa sekolah dasar, dimana media edukasi gizi berbasis android menunjukkan hasil yang lebih baik jika dibandingkan dengan website dan media lainnya. Terdapat perubahan positif terhadap pengetahuan, sikap, dan praktik anak SD setelah edukasi gizi. Oleh karena itu di era jaman milenial sekarang, media elektronik merupakan pilihan yang tepat dalam menyeimbangan tingkat kebutuhan guna membuat perubahan tingkat pengetahuan yang lebih baik untuk memperoleh semua informasi yang dibutuhkan.

\section{Kesimpulan dan Saran}

\section{A. Simpulan}

Berdasarkan hasil penelitian dapat disimpulkan beberapa hal sebagai berikut:

1. Terdapat pengaruh penerapan aplikasi EDIFO dalam meningkatkan pengetahuan secara bermakna dibandingkan dengan metode penyuluhan.
2. Terdapat pengaruh antara karakteristik responden yang meliputi usia, pendidikan, pekerjaan sebagai faktor perancu terhadap peningkatan pengetahuan ibu.

\section{B. Saran}

\section{Saran Teoritis}

Diperlukan penelitian lebih lanjut untuk melihat efektivitas pemakaian system aplikasi android bukan hanya pada kebutuhan nutrisi, tapi pada kebutuhan ibu hamil secara menyeluruh.

\section{Saran Praktis}

Perlu adanya pembaharuan aplikasi baik dari segi tampilan maupun fitur sesuai dengan kebutuhan ibu hamil dalam upaya untuk meningkatkan pengetahuan ibu hamil tentang gizi seimbang melalui aplikasi.

\section{Daftar Pustaka}

Afrilia, E. M. (2017). Hubungan Karakteristik Ibu Dengan Pengetahuan Tentang Gizi Seimbang Bagi Ibu Hamil Di Puskesmas Kecamatan Palmerah Tahun 2013. IMJ (Indonesian Midwifery Journal), 1(1), 45-53.

Almatsier. (2011). Jakarta : Penerbit PT Gramedia Pustaka Utama. Baliwati. In Prinsip Dasar Ilmu Gizi. Jakarta.

Deviyanty, D., Zulfiana Dewi, SKM., M., \& Sajiman, S.KM., M. G. (2017). Perbedaan Metode Penyuluhan Gizi Terhadap Tingkat Pengetahuan Ibu dan Tingkat Konsumsi Anak Usia Dini. 2015-2017.

Handayani, D. (2014). Faktor-Faktor Determinan Status Gizi Ibu Hamil. Jurnal Al-Maiyyah, 7(1), 34-52. 
Hasanah, D., Febrianti, F., \& Minsarnawati, M. (2013). KEBIASAAN MAKAN MENJADI SALAH SATU PENYEBAB KEKURANGAN ENERGI KRONIS (KEK) PADA IBU HAMIL DI POLI KEBIDANAN RSI\&A LESTARI CIRENDEU TANGERANG SELATAN. Jurnal Kesehatan Reproduksi.

Kementrian Kesehatan RI. (2014). Pedoman PGSKesehatan,. Pedoman Gizi Seimbang, 199.

Mamuroh, L., Sukmawati, S., \& Widiasih, R. (2019). Pengetahuan Ibu Hamil tentang Gizi Selama Kehamilan pada Salah Satu Desa di Kabupaten Garut. Jurnal Ilmiah Keperawatan Sai Betik, 15(1), 66.

Mariana, D., Wulandari, D., \& Padila. (2018). Hubungan Pola Makan dengan Kejadian Anemia Pada Ibu hamil Di wilayah Kerja Puskesmas. Hubungan Pola Makan Dengan Kejadian Anemia Pada Ibu Hamil Di Wilayah Kerja Puskesmas, 1(9), 1689-1699.

Narasiang, B. R., Mayulu, N., \& Kawengian, S. (2016). Gambaran pola konsumsi makanan pada ibu hamil di kota Manado. Jurnal EBiomedik.

Notoatmodjo, S. (2012). Promosi Kesehatan dan Perilaku Kesehatan (edisi revisi 2012). In Jakarta: rineka cipta.

Perdana, F., Madanijah, S., \& Ekayanti, I. (2017). Pengembangan media edukasi gizi berbasis android dan website serta pengaruhnya terhadap perilaku tentang gizi seimbang siswa sekolah dasar. Jurnal Gizi Dan Pangan.

Puli, T., Thaha, A. R., Program, A. S., Ilmu, S., Fakultas, G., Masyarakat, K., \& Hasanuddin, U. (2014). Socio-Economic Relations with Chronic Energy Deficiency (CED) for Preconceptions Women in Makassar. 1-7.

(C) Poltekkes Kemenkes Jakarta I

Jl. Wijaya Kusuma No. 47-48 Cilandak Jakarta Selatan, Indonesia email: jurnalquality@poltekkesjakarta1.ac.id
Rahim, R., Lubis, S. A., \& Akhiyar, D. (2018). Perancangan Aplikasi Pemenuhan Kebutuhan Gizi pada Ibu Hamil dengan Metode Cooper Berbasis Website. Teknik Dan Informatika, 5, 40.

Retnaningsih, B. (2010). HUBUNGAN

PENGETAHUAN IBU HAMIL TENTANG

GIZI DENGAN STATUS GIZI IBU HAMIL TRIMESTER III DI PUSKESMAS COLOMADU II KARANGANYAR. Karya Tulis Ilmiah.

Sudirman. (2016). APLIKASI PANDUAN DAN MONITORING IBU HAMIL BERBASIS ANDROID. Skripsi.

Wawan, A., \& Dewi, M. (2011). Teori \& Pengukuran. Pengetahuan, Sikap, Dan Perilaku Manusia. Yogyakarta: Nuha Medika. 